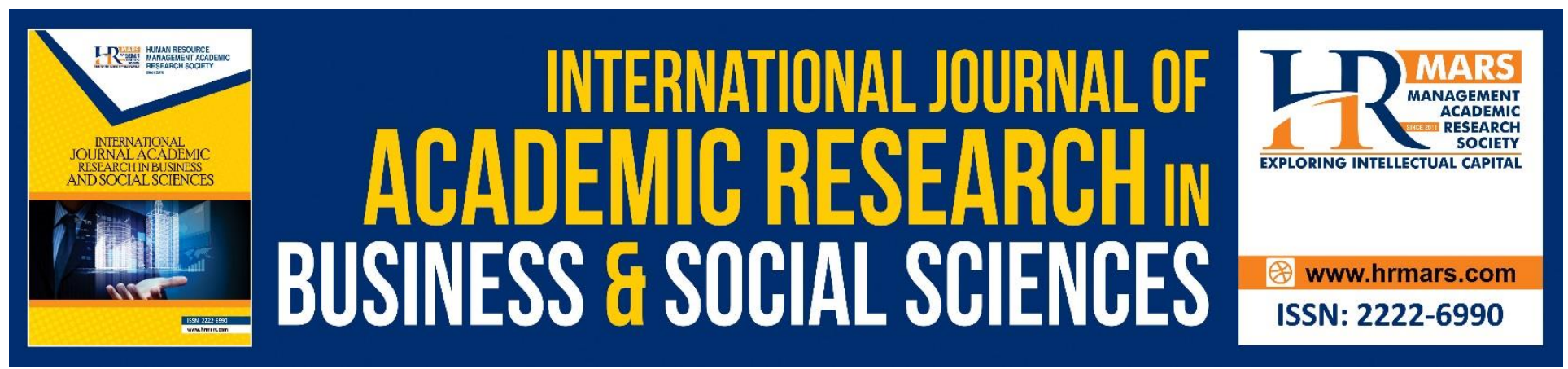

\title{
Expression Style of Woman Preacher towards their Family
}

Dayang Sakini Mohd Kadri, Khazri Osman, A'dawiyah Ismail

To Link this Article: http://dx.doi.org/10.6007/IJARBSS/v10-i5/7428

DOI:10.6007/IJARBSS/v10-i5/7428

Received: 28 March 2020, Revised: 29 April 2020, Accepted: 12 May 2020

Published Online: 25 May 2020

In-Text Citation: (Kadri \& Ismail, 2020)

To Cite this Article: Kadri, D. S. M. K. O., \& Ismail, A. (2020). Expression Style of Woman Preacher towards their Family. International Journal of Academic Research in Business and Social Sciences, 10(5), 1025-1033.

Copyright: (C) 2020 The Author(s)

Published by Human Resource Management Academic Research Society (www.hrmars.com)

This article is published under the Creative Commons Attribution (CC BY 4.0) license. Anyone may reproduce, distribute, translate and create derivative works of this article (for both commercial and non-commercial purposes), subject to full attribution to the original publication and authors. The full terms of this license may be seen

at: http://creativecommons.org/licences/by/4.0/legalcode

Vol. 10, No. 5, 2020, Pg. 1025 - 1033

http://hrmars.com/index.php/pages/detail/IJARBSS

JOURNAL HOMEPAGE

Full Terms \& Conditions of access and use can be found at http://hrmars.com/index.php/pages/detail/publication-ethics 


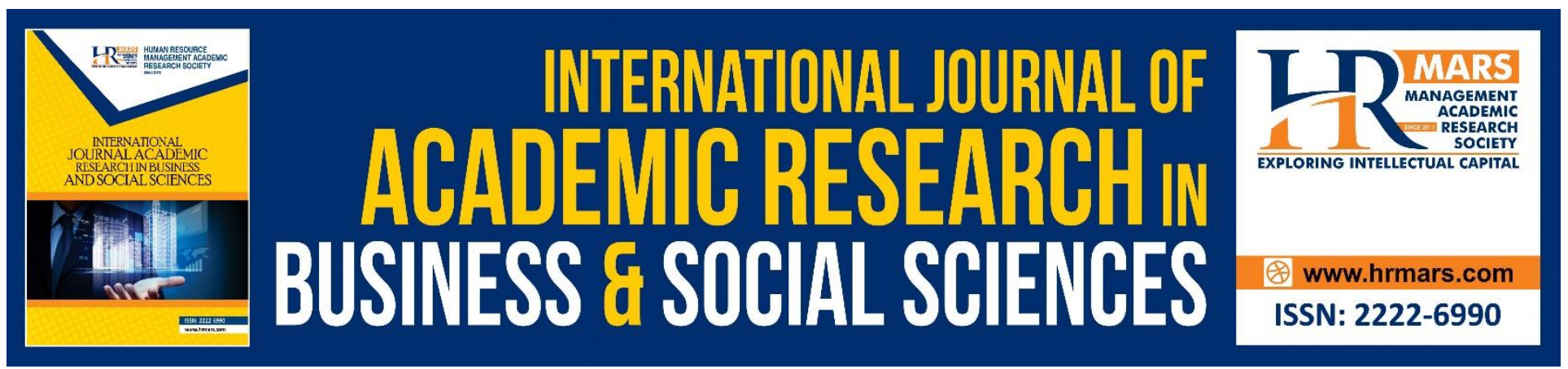

\title{
Expression Style of Woman Preacher towards their Family
}

\author{
Dayang Sakini Mohd Kadri, Khazri Osman, A'dawiyah Ismail \\ Da'wah and Leadership Studies, Faculty of Islamic Studies, National University of \\ Malaysia \\ Email: dayang@kuipsas.edu.my,khazri@ukm.edu.my, ada@ukm.edu.my
}

\begin{abstract}
In a family institution, communication is an important aspect of delivering Islamic teachings. The role of women is very much needed in a family institution especially as a communicator of Islamic teachings and as a husband's helper in educating family members towards goodness. Errors in communication cause misunderstandings, even hurting one another as well as contributing to the divorce and separation of family members. Therefore, this article discusses the style of expression among women preachers in the family. A qualitative study was conducted using thematic content analysis techniques using ATLAS.ti 8 software. The study analysis found that there were ten expression styles of Islamic preaching that Islam recommends for female preachers to use in their families: polite, humorous, truthful and honest, prudent, storytelling based, advice, clear and orderly, gentle, affectionate, and easy to understand. The findings of this study can serve as a reference to women in order to improve the quality of women's da'wah (proselytism in Islam) communication with their family members while achieving harmony in the household.
\end{abstract}

Keywords: Expression Style, Communication, Preacher, Woman, Family.

\section{Introduction}

The family is an institution that plays a major role in the formation of human beings in moral, akhlaq (virtue, manners) and religious aspects (Paizah, 1991). In the early stages, Islam taught its people to choose a life partner based on certain criteria including the emphasis on religion (Hadith narrated by al-Bukhari). This is to ensure harmony and happiness in the household. Paizah Ismail (1991) stated that a woman who lacks a strong religious foundation will deviate from her duties and may damage her household. The Prophet said:

The world is enjoyment and the best enjoyment in the world is a righteous woman. (Hadith narrated by Muslim)

A pious woman in a family is responsible for guiding her family members toward righteousness. This explains her role as a preacher in the family. Like men, women also carry heavy responsibilities in doing $d a^{\prime} w a h$ (proselytism). In the da'wah work, there are more specific activities for women such as giving birth and breastfeeding. Furthermore, a mother can be said to be the first 
preacher to communicate with the newborn child. Therefore, in addition to the role of women as wives, mothers and daughters-in-law, they also play a role in conveying Islamic messages and reprimanding for the sake of establishing a dignified and virtuous human capital. According to Abdul Aziz (2001) a preacher needs to master the skills and techniques of the approach appropriate to the target audience. It is also no exception for women preachers to convey their preaching through the appropriate skills, techniques and approaches to their family members. The main skill in delivering da'wah is the communication skills.

Communication is a process that facilitates the formation of cohesion and coordination within the family. Positive and effective communication is the foundation for building a good family. As children grow up, they begin to develop their identity and make decisions. The study of Howard L. Barnes \& David H. Olson (1985) shows that, when parents and their adolescent children communicate well, the love and relationships become stronger, thus facilitating the problem solving. This study is also supported by several other researchers who believe that family relationships are strengthened when parents and children communicate well so that all family members feel loved, cherished and honored (Ibrahim, Mustapha, Perdani, Ahmad, Nawi, 2018).

In the da'wah communication, there are four basic elements that are needed: the preacher as a communicator, the message conveyed, the approach used in the preaching and the purpose of achieving the mission and objectives of the preaching (Tasmara, 1997). In this article, women play the role of preachers, the content of the presentation and the teachings of pure values are the messages, the style of expression is the approach and practice of good manners and obedience to the commandments of Allah SWT is the goal to be achieved.

Therefore, this article will discuss the appropriate style of expressions for women preachers to apply to their family members.

\section{Research Problems}

According to divorce statistics from the Department of Statistics Malaysia, there are 24,063 cases for 2017 and 2018 have been reported. Similarly, a report from the mass media, Astro Awani on September 17, 2019 found that the causes of divorce were due to lack of understanding and communication problems. Without effective communication, it can lead to a negative situation for the spouse. Communication plays an important role in building mutual understanding, especially between husband and wife. Communication problems can occur not only between the husband and wife, but also between the parents and children. Lack of attention and communication in the family can cause children to be influenced by negative things, which may lead to bad personality and negatively influence their actions (Hadi, 2015). According to Ahmad and Nazri (2017), they stated that a Muslim family who has problems is due to parents' lack of communication with their children. These weaknesses can cause misunderstandings and make family members misunderstand each other.

The use of ambiguous communications causes family members to misunderstand the meaning of the message being conveyed. Sangra Juliano's study found that women often use many questions when communicating that can cause confusion and dispel the true meaning of messages (Juliano, 2015). There is no denying that women have a wide vocabulary to describe their emotions and aesthetics. Women have been taught to express their feelings. However, not all family members understand what they are trying to convey if communication is unclear.

Incorrect choice of expression will cause family members to feel offended and thus cause them to distance themselves and make it difficult to express anything to their family members 
especially to the parents. Fauziah Ismail and Bahiyah Omar's (2018) study shows that the form of communication behaviors that people generally do not like are a communication controlled by one side, speaking loudly, not showing empathy, as well as giving orders and needing people to obey those orders. Communication that is 'biased' makes family members felt less comfortable with the communicator. This in turn causes family institutions to break up.

If the style of expression in a communication is conveyed through the use of inappropriate expressions, then the communication is ineffective.

In fact, good communication is able to convey the right message to the recipient, thus creating a positive impact on family members. Therefore, in order to create a positive family atmosphere, good communication needs to be practiced within each family (Astuti 2011).

\section{Research Methodology}

This study was conducted qualitatively through the thematic content analysis techniques. The data were analyzed from previous studies and other reading materials in the form of print or electronic media which reinforces the research objectives.

\section{Result and Discussion}

After the analysis, the researcher found that there were ten expressions that female preachers could use for family members in inviting and reprimanding towards goodness: polite, humorous, truthful and honest, prudent, storytelling based, advice, clear and orderly, gentle, affectionate, and easy to understand.

\section{Polite Expression}

A polite expression of the female preacher can be seen in terms of her behavior and language use. The language used not only determines the cultural pattern but also the thinking way and pattern. Someone who interacts in a polite language is said to have a high courtesy, while someone who speaks vulgar and impolite language is considered rude. In Islam, Allah SWT teaches people to be polite in the conversation as stated in Surah Al-Isra' verse 23; "And your Lord has decreed that you not worship except Him, and to parents, good treatment. Whether one or both of them reach old age [while] with you, say not to them [so much as], "uff," and do not repel them but speak to them a noble word." (Quran, Surah Al-Isra ': 23)

Good and harmonious communication can increase the enjoyment and peace of soul, as well as the intimacy and devotion to Allah Almighty (A'dawiyah, 2016). Therefore, the speaker must display good manners and courtesy, by displaying good behavior and attitude. Modesty covers nonverbal languages, such as facial expression, body language, and so on. In other words, polite expressions also include the use of good, polite, and civilized language exemplifying personal dignity and showing respect to those who speak.

\section{Humorous and Figurative Expression}

Humor is something that is amusing in story etc. A humor can create a happy atmosphere and make others smile and laugh. The Messenger of Allah (peace be upon him) also joked with the family members and friends r.a. This is also acknowledged by Aishah r.a. that he socialize with his wife like everyone else with a smile and laughter. Tirmizi (1988) records that a man came to the Messenger of 
Allah (peace be upon him) asking that he be given animal for ride. The prophet agreed but not the camel, instead the calf. Then the man protested in surprise because the camel was not fit for ride. He said, "Don't all she camels give birth to the calf?"

Islam teaches its people to practice moderation in many matters including jokes. Once you have crossed the line of sharia, the joke should be stopped. Some jokes that are prohibited are; to joke about words or acts of religion whether they are obligatory or supererogatory act of worship. Saying untruthful things are prohibited even when joking, because lies are the cause of all despicable things. Even the person who hears it should also stay away.

\section{Truthful and Honest Expressions}

Ahmad bin Hanbal (2001) recorded a hadith narrated by Ubadah bin al-Samit, that the Messenger of Allah (may peace be upon him) said: Whoever observes six things, I guarantee he will go to heaven; be true to your word, keep your promise, keep your self-respect, lower your gaze and never beg.

In another hadith, narrated by Dawud (2009), from Abdullah bin Abi al-Hamsa', he had made an appointment to meet the Messenger of Allah (peace be upon him) somewhere before he became the prophet. However, Abdullah forgot. After some time passed, he remembered and immediately went to the place. He found that the Messenger of Allah was still waiting. He said, "O young man, you have troubled me. I've waited so long."

Women preachers who practiced right and honest attitude have the faith that save them from the small and large shirk (idolatry or polytheism), ready to sacrifice for the sake of religion, and repent when sinning. She also loved the saaleheen (the righteous) and the sadeeq (close companions).

\section{Prudent Expressions}

Prudent means virtuous, civilized, and wise in expression. Women preachers need to be careful in choosing words that do not offend family members, especially in reprimanding mistakes. Communication is important in resolving family conflicts and shaping early adolescent and adult psycho-social adjustment (Manap, Baba, Rahman and Rais, 2013). In resolving conflicts, humans are often tested with emotion control. Usually, when angry, emotions can be disturbed. Various words you want to say without thinking ahead. In Islam it is also advisable to be prudent in conversation and not to utter harsh words as mentioned in Surah Fussilat verse 33 which means; "And who is better in speech than one who invites to Allah and does righteousness and says, "Indeed, I am of the Muslims." (Quran, Surah Fussilat: 33)

In an article in a local newspaper, it is said that words spoken in anger are often not constructive, but are damaging to the self-esteem of others (Syarha, 2018). For example, when a husband just comes home and the eldest spilled water on the floor that caused the husband to fall. Then the husband raised his voice and scolded the child. As a woman preacher serving as a wife, what kind of words should be used? "You are always rude to the children. The child will follow your step later." This is the blaming emotion. However, using a more prudent sentence such as, "You're tired. Just rest first, let me clean it up. My dear, your dad is tired. Give dad some time. Let's be with mom first." The choice of words that is soothing albeit a simple one may have a positive effect and can control the emotions of all family members. Therefore, a woman preacher needs to be wise and prudent in choosing words that fit her current situation. 


\section{Storytelling based Expression}

Almost all groups of people like to hear stories. The storytelling method that employs a two-way communication can strengthen the relationship between the preacher and the family. In addition to gaining knowledge, children also receive information and learn a lesson from each story. Abdullah (2007) explains that the da'wah approach that incorporates storytelling facilitates the target audiences to easily understand the message, and in turn drives their attitudes and behavior change.

Among the benefits of the storytelling method are that it creates a relaxed and informal atmosphere, reduces stress, can be infused with jokes and physical touches. When it comes to a particular plot, the children can imagine themselves acting as characters in the story.

The Quran as the primary source of authentic stories presents some interesting stories such as the story of prophets, Zu al-Qarnayn, ashab al-sabt, Maryam the mother of Jesus a.s. and Pharaoh. However, there are also stories that have always been the choice of preacher but of questionable authenticity of the source. One of such stories was the story of Alqamah that was said to be disobedient to his mother even though he is well known among the Companions as a good and pious person. There were also the story of Tha'labah who refuse to pay zakah (alms), which Ibn Hajar alAsqalani (1994) refuted, saying "I tend to say that this story is not valid."

\section{Expression of Advice}

Fariza Md Sham's (2015) study showed that the adolescents experienced emotional changes between the childhood and adulthood phases. Therefore, the women preacher in the family should know and deepen their psychology knowledge in order to provide advice and knowledge that children can understand and accept openly. Advice cannot be hidden because it is one of the few Muslim rights that need to be fulfilled. Before giving advice, women preachers should correct her intention that she gives the advice because of Allah Almighty, wants to lead their family to the right path and not to gloat. Practice giving the advice privately, as Kharaz (2009) cites a poem from the Imam Shafi'i:

Advise me when I am on my own; avoid giving me advice in front of the audience. Advice in front of audience, an insult I don't want to hear.

Advice can be given in many forms such as prose or poetry. In Arabic, for example, there are words that are manzum and manthur. The manthūr expression is very common in Arab society, but its attractiveness is somewhat lacking. As for the manzūm such as poetry, though the numbers are few but the value is high (Khazri Osman \& Faizol Azham Mohamed 2018).

Meanwhile, Zulkefli and S.Salahudin (2016) propose that the following manners be considered as a step such as the topic of conversation between the communicator and the recipient should be related to good and beneficial things, should avoid expressing words that do not bring benefits, do not lie in the speech, not expose others' flaws, not belittle others and to maintain their manners when facing differing views.

\section{Clear and Orderly Expressions}

A clear and orderly style of expression is when a preacher communicates without using sentences that are too long and do not speak too fast (Damia \& Zulkefli, 2017). Women preachers need to avoid language that is difficult to understand or unpopular. According to Amru bin al-As, the words are like medicine, they are useful in small quantity but can kill a person if overdosed (Thaalabi, 1992). There are times when it is important such as using balaghah to convey high meaning clearly through words 
that are correct and eloquent and that can influence others. The words should fit the mood and atmosphere of the target audience.

For children, the age between two and five years is known as the communication age. To encourage children's understanding of language, female preachers should use children's interests or actions to communicate and be positive when the children respond. In addition, rhythmic words should also be used such as "seed, feed, weed." Bombastic words should be replaced with words that are more understandable such as sophisticated (modern), brilliant (good), pure (true), and so on, depending on the age of the children.

\section{Gentle Expressions}

The use of gentle words is more acceptable to the mad'u than harsh words. This guarantees a good relationship with the family members. When communication between parents and children is well established, family relationships are closer and create love and facilitate problems solving (Yusooff, 2011). Islam told the story of Moses as he preached to Pharaoh in Surah Taha. Allah SWT commanded Moses to speak gently in delivering his messages (Quran, Surah Taha 20: 43-44).

In addition, it is a woman's nature to be loving and gentle. Therefore, Allah Almighty gives the task of conceiving and giving birth to women. This difference in attitude is an advantage for women preachers to invite family members towards goodness. The most effective method of displaying this gentle expression is to persuade family members to listen to their requests.

\section{Affectionate Expressions}

A female preacher not only faces her children but also her husband as the living partner. She should accept the husband's shortcomings even if every woman longs for a perfect husband. Jealousy needs to be in moderation and in a justified situation. Affectionate and harmonious communication or interaction can foster closer relationships towards the formation of a quality family according to Islam (A'dawiyah, 2016). Example of affectionate expression are discussions about visiting hometowns, going for picnics, doing social projects and talking about other topics of interest to all parties.

In addition, a warm and welcoming endearment for husband and children can deepen relationship, provide a positive perspective, express affection, as well as increasing love and respect. Examples of affectionate endearment for children are based on the names of Prophet Muhammad's companions, or talked about their ambitions such as doctors, ustaz, lawyer, pilot, teachers and so on. Meanwhile, the appropriate affectionate endearments for husband are zawji, habibi, my dear, qalbi and others. Aishah r.a. also called the prophet with the greatest title, O Messenger of Allah, so did he who called her 'Ya Humaira'.

\section{Expressions that are Easy to Understand}

Mubarok (1997) lists the characteristics of a da'wah language which is simple and easy to understand and is light in the presentation, moderate and accessible to listeners. Allah SWT also sent the Messenger to his people in a language that was easily understood so that the followers can understand his explanations as stated in the Qur'an, " And We did not send any messenger except [speaking] in the language of his people to state clearly for them, and Allah sends astray [thereby] whom He wills and guides whom He wills. And He is the Exalted in Might, the Wise." (al-Qur'an, Ibrahim 14: 4) 
INTERNATIONAL JOURNAL OF ACADEMIC RESEARCH IN BUSINESS AND SOCIAL SCIENCES

Vol. 10, No. 5, May, 2020, E-ISSN: 2222-6990 @ 2020 HRMARS

Therefore, the female preachers need to use more relaxed and comfortable expressions to their family members according to their language adjustments. For example, heavy things related to bills or finances are not appropriate topic to talk with small children. They do not yet understand their parents' burdens and responsibilities.

Instead, the appropriate topics are about the application of the basic principles of faith, worship and morals to children. Education on prayer, fasting and other acts of worship also need to be conveyed in lighter and interesting expressions. In addition, the production of video presentation of religious content in the form of cartoons has been widely circulated in the mass media. The task of women preacher is to explain it more clearly to the younger children. This does help the preacher in giving early education to the family members.

\section{Conclusion}

From this study, it can be concluded that a good and appropriate style of expression helps to convey the message more clearly. Recipients can receive a message with calm and ease, thus further enhance their good morality by applying ten styles of expression that women preachers use to their families that are polite, humorous, truthful and honest, prudent, storytelling based, advice, clear and orderly, gentle, affectionate, and easy to understand. The use of this style of expression can also keep the good relationships between speakers and listeners. This can prevent the occurrence of strife, dissension or divorce in the family if this style of expression is not used properly.

This style of expression of female preacher is not only suitable for use by female preachers, but it should also be practiced by all preachers regardless of gender. In addition, the training, workshops, seminars and courses on this expression style should always be held for women so that they can practice it in their family.

\section{Corresponding Author}

1. Dayang Sakini binti Mohd Kadri, Lecturer, Department of Da'wah, Faculty of Islamic Studies, Sultan Ahmad Shah Islamic University College, Pahang Kuantan (KUIPSAS), dayang@kuipsas.edu.my.

2. Dr Khazri bin Osman, Lecturer, Centre of Da'wah and Leadership, Faculty of Islamic Studies, National University of Malaysia, 43600, Bangi, Selangor, khazri@ukm.edu.my.

3. Prof Madya Dr A'dawiyah binti Ismail, Lecturer, Centre of Da'wah and Leadership, Faculty of Islamic Studies, National University of Malaysia, 43600, Bangi, Selangor, ada@ukm.edu.my.

\section{References}

Ahmad, A. D., \& Nazri, M. A. (2017). Komunikasi Keluarga Berdasarkan Uslub Nabi SAW. Jurnal alTurath, 2(1).

Aini, Z., Don, G. A., Mokhtar, I. A., \& Sad, D. H. (2018). Pengamalan Bentuk-Bentuk Komunikasi Dakwah Pendakwah Orang Asli. Al-'Abqari, 13, 103-116.

Aini, Z., \& Suyurno, S. S. (2016). Pengantar komunikasi dakwah. Bangi: Jabatan Pengajian Dakwah dan Kepimpinan. UKM.

Asqalani, H. I., \& Ali, A. (1994). Al-Ișabah. Beirut: Dar al-Kutub al-cllmiyyah. 
INTERNATIONAL JOURNAL OF ACADEMIC RESEARCH IN BUSINESS AND SOCIAL SCIENCES

Vol. 10, No. 5, May, 2020, E-ISSN: 2222-6990 @ 2020 HRMARS

Bernama. (2019). Kes cerai pasangan Islam di Selangor membimbangkan . Astro Awani. Retrieved from http://www.astroawani.com/berita-malaysia/kes-cerai-pasangan-islam-di-selangormembimbangkan-217731

Damia, N., \& Aini, Z. (2017). Bahasa da`i dalam komunikasi dakwah kepada masyarakat Orang Asli. Al-Hikmah, 9(1), 110-127.

Dawud, A., \& Ash'ath, S. (2009). Sunan Abi Dawud. Shucayb Arnauț (pnyt.). Dar alRisalah al-Hadithah.

Hanbal, A., \& Ahmad, M. (2001). Musnad al-imam ahmad bin ḥanbal. Shucayb al-Arnauṭ (pnyt.). Beirut: Muassasah al-Risalah.

Hassan, A. (2007). Komunikasi berkesan dlm berdakwah dengan efektif. Selangor: PTS Publications \& Distributors.

Howard, L. B., \& David, H. O. (1985). Parent-adolescent communication and the circumplex model. Child Development 56(2):438-47.

Ibrahim, H., Mustapha, M., Perdani, J., Ahmad, M. H. P., Nawi, H. N. (2018). Peranan dan Tanggungjawab Ibu Bapa dalam Pengasuhan Anak dan Remaja. Asian Social Work Journal (ASWJ), 3(5).

Ismail, A. (2016). Keluarga berkualiti dalam kalangan wanita berkerjaya. Selangor: Penerbit UKM.

Ismail, F., \& Omar, B. (2018). The effects of physician communication style on patient satisfaction. Jurnal Komunikasi: Malaysian Journal of Communication 34(3): 73-95. doi:10.17576/JKMJC2018-3403-05

Ismail, N. F., \& Ashaari, M. F. (2018). Komunikasi Dakwah dalam Interaksi Menerusi WhatsApp. 6(1), 33-39.

Ismail, P. (1991). Asas pembinaan keluarga islam. Mahir Publication Sdn. Bhd. Kuala Lumpur.

Ismail, S., Rasit, R. M., \& Aini, Z. (2019). Mesej Komunikasi Keluarga dalam Surah Luqman Family Communication Messages in Surah Luqman. 6, 201-213.

Juliano, S. (2015). Jurnal Ilmu Politik dan Komunikasi. Komunikasi Dan Gender : Perbandingan Gaya Komunikasi Dalam Budaya Maskulin Dan Feminim, V, 19-30.

Jumcah, K. (2009). Mawsūcah Al-Akhlaq. Kuwait: Maktabah Ahl al-Athar.

Manap, J., Baba, S., Rahman, S.N \& Rais, H. (2013). Pendekatan Komunikasi Keibubapaan dalam Keluarga Ibu Mithali. Journal of Human Development and Communication. 2(1).

Zin, M. A. A (2001). Metodologi dakwah. Kuala Lumpur: Penerbit Universiti Malaya.

Mubarok, A. (1999). Psikologi dakwah. Jakarta: Pusaka Firdaus.

Noh, C. H., \& Yusooff, H. (2011). Corak Komunikasi Keluarga Dalam Kalangan Keluarga Melayu di Terengganu. Jurnal Hadhari, 3(2).Kadri, D. S. M. K. O., \& Ismail, A. (2020). Expression Style of Woman Preacher towards their Family. International Journal of Academic Research in Business and Social Sciences, 10(5), 987-996.

Syarha, F. (2018). Marah berhemah. Harian Metro.

Retrieved from https://www.hmetro.com.my/addin/2018/11/397824/marah-berhemah.

Tasmara, T. (1996). Komunikasi dakwah. Jakarta: Penerbit Gaya Media Pratama.

Thacalabi \& Muhammad, A. (1992). Al-icjaz wa al-ijaz. Beirut: Dar al-Nafais.Kadri, D. S. M. K. O., \& Ismail, A. (2020). Expression Style of Woman Preacher towards their Family. International Journal of Academic Research in Business and Social Sciences, 10(5), 987-996. 